\title{
TOISEUS TAHATTOMASTI LAPSETTOMIEN NAISTEN KOKEMANA
}

Kirsi Günther: YTT, yliopistonlehtori, Turun yliopisto
Eeva Ekqvist: YTM, yliopisto-opettaja, väitöskirjatutkija, Tampereen yliopisto
Jenni Katajisto: YTM, koulukuraattori, Kauhajoen kaupunki

kirsi.gunther@utu.fi; eeva.ek.qvist@tuni.fi;jenni.katajisto@gmail.com

Janus vol. 28 (3) 2020, 273-289

\section{Tiivistelmä}

Tahaton lapsettomuus koskettaa yhä useampaa suomalaista naista. Tarkastelumme kohteena ovat tahattomasti lapsettomien naisten toiseuden kokemukset, jotka syntyvät, kun naiset vertaavat itseään muihin naisiin sekä yhteiskunnallisiin äitiysodotuksiin tehden eroa, arvottaen ja tuottaen erilaisuuden ja samanlaisuuden kokemuksia suhteessa toisiinsa. Kysymme: miten tahattomasti lapsettomat naiset kokevat toiseuden sekä ketkä ja mitkä tekijät synnyttävät heille toiseuden kokemuksia? Aineistona käytimme tahattomasti lapsettomien naisten kirjoituksia $(\mathrm{N}=22)$, joita erittelimme sisällönanalyysin keinoin. Paikansimme kirjoitelmista kolme toiseuden kokemuksen tapaa, jotka pitävät sisällään erilaisia toiseuden tuottamisen dynamiikkoja: 1) Lapsettomuus eriyttävänä kokemuksena, 2) Lapsettomuus yhdistävänä ja voimaannuttavana kokemuksena ja 3) Lapsen saanti toiseutta tuottavana kokemuksena. Naisten kokemus tahattomasta lapsettomuudesta on sekä negatiivisesti että positiivisesti värittynyttä; havaittavissa on myös vertaistuella saatuja yhdistäviä ja voimaannuttavia kokemuksia.

\section{JOHDANTO}

Suomalaisten lapsettomuusluvut ovat nousseet sitten 1990-luvun 15 prosentista lähes 20 prosenttiin (Miettinen ym. 2014). Anneli Miettisen $(2015,3) \mathrm{mu}-$ kaan Suomeen on kasvanut kuilu lapsisyntyvyyden lisääntymisen tavoitteen ja toteutumisen välillä. Tätä ilmiötä on selitetty muun muassa sosiaalisten instituutioiden ja arvojen heikentymisellä, lasten aiheuttamilla kustannuksilla, tasa-arvokehityksellä ja lasten saannin lykkäämisellä myöhemmäksi sekä lapsettomuuden lisääntymisellä (ks. esim. Rotkirch ym. 2017). Lapsettomuus on monimuotoinen ilmiö (Tanturri \& Mencarini 2008). Sen syynä voivat olla niin terveydelliset kuin elämäntilanteeseen ja sosiaalisiin tekijöihin liitty- vät seikat. Lapsettomuus jaetaan usein kahteen kategoriaan: vapaaehtoiseen ja tahattomaan lapsettomuuteen (ks. esim. Carmichael \& Whittaker 2007). Vapaaehtoinen lapsettomuus tarkoittaa sitä, että yksilö valitsee, ettei hän halua lapsia. Yksilön valintaan vaikuttavat monet tekijät, kuten taloudelliset ja/tai elämäntilanteelliset seikat. Valinta voi olla lopullinen, tai se voi myöhemmin muuttua. Usein vapaaehtoinen lapsettomuus on yksilölle elämäntapa. (Miettinen \& Rotkirch 2008, 16-17, 120; Miettinen 2010; Rotkirch ym. 2017; ks. myös Gillespie 2000.) Tässä artikkelissa tarkastelemme tahatonta lapsettomuutta, jolla tarkoitamme biologista ja sosiaalista ilmiötä, joka ilmenee kyvyttömyytenä tulla raskaaksi tai raskaus päättyy keskenmenoon (ks. esim. Greil 
ym. 2010; Kettula-Pihlaja ym. 2015; Watkins \& Baldo 2004).

Maija Tulppalan $(2012,2082)$ mukaan lapsettomuus kokemuksena koskettaa naisen kaikkein yksityisintä. Naisten kokemuksiin vaikuttavat niin yhteiskunnalliset ja kulttuuriset kuin sosiaaliset odotukset (Isola 2012; Lehto 2017; Morison ym. 2016; Nätkin 1991; Parry 2005). Francesca Fiorin ja kumppaneiden $(2017,342)$ mukaan lapsettomuuden vaikutukset voivat heijastua yksilön hyvinvointiin ja kokemukseen siitä, miten tyytyväinen hän on elämäänsä. Lapsettomuuden tahattomuus tuottaa oman lisänsä lapsettomuuden aiheuttamiin kokemuksiin (ks. esim. Benasutti 2003; Greill ym. 2010; Katajisto 2016; Luk \& Loke 2015; Parry 2004; Ulrich \& Weatherall 2000; Watkins \& Baldo 2004). Lapsettomuudesta voi seurata eristäytymistä ja negatiivisia toiseuden kokemuksia, tai sen kautta nainen voi saada uusia merkityksiä elämälleen (Graham 2015, 176). Esimerkiksi nainen saattaa kokea epäonnistumista siinä, ettei hän kykene täyttämään läheisten odotuksia ja toiveita tulla vanhemmaksi (ks. Tulppala 2012). Hän voi myös kokea itsensä toiseksi suhteessa naisiin, jotka voivat saada lapsia. Tässä artikkelissa tarkastelun kohteeksi nostamme tahattomasti lapsettomien naisten kokemukset toiseudesta. Kysymme: miten tahattomasti lapsettomat naiset kokevat toiseuden sekä ketkä ja mitkä tekijät synnyttävät heille toiseuden kokemuksia? Näihin kysymyksiin etsimme vastausta naisten kirjoitelmista $(N=22)$.

Kirjoitelmista on paikannettavissa käsitteitä, joiden avulla naiset kuvaavat ja selittävät toiseuden kokemuksiaan. Toiseudella tarkoitamme naisten kirjoitta- mia kokemuksia, joissa he tekevät eroja ja arvottavat toisia ihmisiä ja samalla tuottavat erilaisuuden ja samanlaisuuden kokemuksen suhteessa toisiin. Toiseus tuo esiin sen, miten näemme itsemme ja toisemme (Hall 1999, 98). Tahattomasti lapsettomalle naiselle toiseuden kokemus syntyy, kun hän tarkastelee itseään suhteessa ympäröivään maailmaan ja muihin naisiin (ks. toiseudesta Juhila 2004; Kulmala 2006, 70-72). Apuna toiseuden kokemusten paikantamisessa kirjoitelmista käytämme sisällönanalyysia. Kokemusten tarkastelussa nousee usein esiin negatiivisia eriyttäviä toiseuden kokemuksia (ks. Julkunen 2010; Mäkinen 2008). Artikkelissa tahdomme nostaa esiin myös lapsettomuuteen liittyviä positiivisia jaetun ja samankaltaisuuden synnyttämiä kokemuksia. Niiden tunnistaminen voi auttaa naisia selviytymään negatiivisista kokemuksista ja samalla tuottaa tietoa tahattomaan lapsettomuuteen liittyvien palvelujen kehittämiseen positiivisen tuen näkökulmasta.

Tahatonta lapsettomuutta on tutkittu paljon hoito- ja lääketieteiden viitekehyksissä (ks. esim. Kuivasaari-Pirinen 2013; Repokari 2008; Yli-Kuha 2012), mutta sosiaalitieteellistä ja erityisesti sosiaalityön tutkimusta aiheesta on tehty verrattain vähän (ks. esim. Hinkkanen 2009; Malin 2006; Miettinen 2011, 7), minkä vuoksi siihen on tärkeää kiinnittää tutkimuksellinen katse. Sen sijaan toiseutta ja sen tuottamia kokemuksia on sosiaalitieteissä ja sosiaalityössä tarkasteltu monesta suunnasta. Muun muassa Anna Kulmala (2006) on tutkinut mielenterveysongelmasta kärsivien toiseuden kokemuksia ja Laura Huttunen (2004) on tarkastellut toiseutta maahanmuuttajien näkökulmasta. 
Lapsettomuuden näkökulmasta aihetta on kuitenkin tutkittu verrattain vähän eikä Gayle Letherbyn (2002, 285-286) mukaan riittävästi. Tällä tutkimuksella haluamme tuottaa lisää tietoa tahattomasti lapsettomien naisten toiseuden kokemuksista.

Artikkeli etenee siten, että ensin pohjustamme tutkimustamme avaamalla tahatonta lapsettomuutta ja toiseutta. Tämän jälkeen kuvaamme tutkimusaineistona olevia naisten kirjoitelmia ja sitä, miten tutkimuksen toteutimme. Analyysiosassa vastaamme tutkimuskysymykseemme erittelemällä tahattomasti lapsettomien naisten toiseuden kokemuksia ja tuomalla esiin erilaisia toiseuden tuottamisen tapoja. Päätämme artikkelin pohdintaan.

\section{TAHATON LAPSETtOMUUS JA TOISEUS}

Naiseus ja äitiys liitetään länsimaisessa kulttuurissa vahvasti yhteen (Häggman 1994; Katajisto 2016; Nätkin 1991; Parry 2005; Rich ym. 2011; Ulrich \& Weatherall 2000). Siru Lehdon (2017, 391) näkemys on, että kulttuurillinen käsikirjoitus ohjaa naisten elämää normein, odotuksin ja vaatimuksin. Rosemary Gillespien (2000, 225) mukaan äitiyttä voidaan pitää jopa naisen merkityksellisimpänä sosiaalisena roolina ja yhteiskunnallisesti merkittävänä tehtävänä (ks. myös Häggman 1994). Beth Turnbull ja kumppanit $(2017,351)$ näkevätkin, että nainen, joka ei noudata tätä kulttuurista käsikirjoitusta, kokee usein toiseutta ja syrjäytymistä elämässään.

Toiseudella tarkoitetaan leimaantumista normaalista poikkeavaksi ja poikke- avan ymmärtämistä vähäarvoisemmaksi (Löytty 2005b, 9). Siten valtasuhteet liittyvät keskeisesti toiseuden tuottamiseen (Löytty 2005a, 162). Toiseuden kokemus syntyy lapsettomalle naiselle silloin, kun hän peilaa itseään muihin naisiin ja ottaa itsensä määrittelyssä sekä kategorisoinnissa huomioon yhteiskunnalliset ja kulttuuriset odotukset sekä sosiaalisten ryhmien näkemykset. Anna Kulmala (2006, 70) määrittelee toiseuden yksilön erilaisuuden, ulkopuolisuuden ja eriarvoisuuden kokemukseksi. Usein tahattomasti lapseton kokee itsensä huonommaksi ja ala-arvoisemmaksi kuin muut, koska hän ei ole kyennyt täyttämään yhteiskunnallista tehtäväänsä. Letherbyn (1999) mukaan nainen ilman lasta määrittyy toiseksi yhteiskunnassa, jossa arvostetaan äitiyttä ja lapsia. Siten äitiys voidaan nähdä samaistumisen tai erottumisen välineenä (Lehto 2017, 393).

Toiseuden käsite on kytköksissä eron käsitteeseen (Hall 1999), jolloin toiseus on eron tekemistä meidän ja muiden välille. Kirsi Juhilan $(2012,180) \mathrm{mu}-$ kaan kategorisointi meihin ja heihin tuottaa aina toiseutta. Samalla kun luokittelemme jonkun henkilön tiettyyn kategoriaan, syntyy hänelle kyseisen kategorian ryhmäjäsenyys (Juhila 2012, 176). Tiettyyn kategoriaan luokittelu antaa vihjeitä siitä, mitä meidän pitäisi kyseisistä henkilöistä ajatella ja millaista toimintaa heiltä odotamme sekä miten se eroaa toiseen kategoriaan kuuluvien toiminnasta. Esimerkiksi tahattomasti lapsettomien naisten kategoriaan on varastoitunut yleistä kulttuurista tietoa muun muassa siitä, miten yhteiskunnassa suhtaudutaan lapsettomiin naisiin. (Ks. Hall ym. 2006; Juhila 2012.) 
Aina kun määrittelemme ja kategorisoimme toisia, teemme samalla vastakkainasettelua ja erontekoja (Jokinen ym. 2004, 16; Löytty 2005a, 165; Löytty 2005b, 9). Kun asetamme naisen tahattomasti lapsettoman asemaan, häntä kuullaan ja tulkitaan kyseisen ryhmän edustajana ja samalla tehdään ero hänen ja lapsen saaneen naisen, äidin, välille. Tahattomasti lapsetonta ja normaalia naista määriteltäessä esille nousevat näitä kahta ryhmää erottavat asiat, mutta myös niitä yhdistävät, samuutta tuottavat asiat (ks. Ulrich \& Weatherall 2000, 323, 333). Vastapuheen avulla tahattomasti lapsettomien ryhmään kuuluvat naiset voivat pyrkiä kyseenalaistamaan, kieltämään tai muuttamaan heihin kohdistuneita määritelmiä (Jokinen ym. 2004, 11). Siten vastapuhe on toiseuden vastustamista. Toiseuteen liittyvä vastapuhe kytkeytyy erontekoihin sekä identiteetin muodostamisen prosessiin (Juhila 2004, 29). Identiteetin muodostamisen prosessissa itseä, kuka olen ja mihin kuulun, määritellään suhteessa toisiin (Hall 1999, 84; Löytty 2005a, 166). Toiset antavat peilauspinnan oman itsen ymmärtämiselle ja identiteetin rakentamiselle (Löytty 2005a, 155-157). Prosessin aikana tahattomasti lapsettomat naiset tekevät erontekoja muihin peilaamalla sitä, mikä tekee heistä erilaisia ja samanlaisia suhteessa toisiin. Kokemus erilaisuudesta tai samankaltaisuudesta voi olla naiselle joko kielteinen tai myönteinen. Toiseutta vastustavan vastapuheen avulla naiset pyrkivät tuottamaan samuutta ja myönteisiä toiseuden kokemuksia sekä kyseenalaistamaan heihin liitettyjä kategorisointeja (ks. Juhila 2004).

Lapsettomat naiset elävät yhteiskunnassamme "toisina" syntyvyyttä nostavan yhteiskuntapolitiikan (Isola 2012, 335; Patosalmi 2011) vahvistaessa lastensaannin normatiivisuutta (Parry 2005). Naisilta odotetaan tietyssä elämänvaiheessa, kuten parisuhteen vakiintuessa, lasta ja vanhemmuutta (Morison ym. 2016; Mäkinen 2008; Nätkin 1991). Usein parisuhteen tavoitteena on perheen perustaminen ja sitä kautta parisuhteen vahvistaminen (ks. Tulppala 2002). Jos lapsen saaminen ei onnistu, voidaan se usein kokea parisuhteessa suurena vastoinkäymisenä, joka tuo muutoksia parisuhteeseen loitontamalla puolisoita toisistaan. Kaikille lapsen saannin vaikeus ei kuitenkaan ole kriisi, vaan se voi lähentää puolisoita toisiinsa ja syventää heidän välistä parisuhdettaan. (Greil ym. 2010, 149; Tulppala 2002.)

Yhteiskunnassa, jossa perhe on arvo ja lapset nähdään naiseuden, aikuisuuden ja vastuullisuuden symboleina, voi tahattomasti lapsettomalle naiselle syntyä kokemus epäonnistumisesta henkilökohtaisesti ja kansalaisena. Itselle asetetut odotukset, kulttuurin ja yhteiskunnan tuottamat velvoitteet sekä sosiaalisiin normeihin liittyvät odotukset jäävät täyttymättä. Epäonnistumisen kokemuksen seurauksena nainen voi kokea vaillinaisuuden tunteita (Katajisto 2016; McCarthy 2008; Ulrich \& Weatherall 2000) ja kyseenalaistaa oman tarkoituksensa ja arvonsa (Benasutti 2003, 52-53; Julkunen 2010; Letherby 2002, 278; McCarthy 2008, 321; Rotkirch ym. 2017). Lapsettomuus voi tuntua yksinäiseltä ja eristävältä, ja nainen voi kokea, että ei saa osakseen ymmärrystä perheenjäseniltä, sukulaisilta tai ystäviltä (Watkins \& Baldo 2004, 396). Tahaton lapsettomuus on useissa tutkimuksissa paikannettu kriisiksi, jo- 
hon liittyy negatiivisia tunteita, kuten toivottomuutta, voimattomuutta ja surua sekä alhaisempaa psyykkistä hyvinvointia (Luk \& Loke 2015).

Tahaton lapsettomuus estää naisen omien unelmien ja yhteiskunnan odotusten täyttymisen; kyseessä ei ole valinta. Raija Julkusen (2010, 242-244) mukaan nykyaikana naisille avautuneet uudet mahdollisuudet eivät ole poistaneet entisï sosiaalisia ja kulttuurisia velvoitteita. Heiltä odotetaan edelleen voimavarojensa panostamista muiden ihmisten hyvinvoinnista huolehtimiseen oman hyvinvoinnin jäädessä toissijaiseksi. Tällöin lapsettomat naiset voidaan leimata itsekkäiksi (Mäkinen 2008, 124), omaan elämään ja uraan panostaviksi toisiksi.

Aina tahattomaan lapsettomuuteen ei kuitenkaan liity vain negatiivisia eriyttäviä toiseuden kokemuksia, vaan siitä on paikannettavissa myös positiivisia kokemuksia, jotka voivat tukea ja kannatella naisia eteenpäin (Herrmann ym. 2011; Kettula-Pihlaja ym. 2015; Räisänen \& Kaunonen 2004; Tulppala 2012). Positiivisen toiseuden kokemus voi syntyä suhteessa toisiin vertaisiin tai puolisoon, joiden kanssa he voivat kokea samuutta ja jakaa kokemuksiaan. Naisten kokeman ahdistuksen on havaittu vähenevän, kun he jakavat kokemaansa muiden kanssa (Watkins \& Baldo 2004). Tutkimuksissa tahattoman lapsettomuuden negatiivisista kokemuksista selviytymistä tukeviksi tekijöiksi on tunnistettu muun muassa yhteiskunnan perhekäsityksen monimuotoistuminen, sosiaaliselta ympäristöltä saatu tuki, itsensä arvokkaaksi kokeminen, arjen mielekkyyden löytäminen, tulevaisuuden uudelleen määritteleminen ja elämän merkityksellisyyden tunne lapsettomuudesta huolimatta (Gameiro \& Finnigan 2017; Kettula-Pihlaja ym. 2015; Su \& Chen 2006; Watkins \& Baldo 2004).

Kathryn Watkinsin ja Tracy Baldon (2004) mukaan naiset pitävät tukitahoinaan puolisoitaan, perhettään, muita lapsettomia naisia, lääkäreitä, hoitohenkilökuntaa ja terapeutteja. Naiset voivat kokea samuutta ja yhtenäisyyttä puolisoidensa kanssa, sillä he jakavat lapsettomuuden surun. Puolison kanssa yhteinen jaettu kokemus voi syventää puolisoiden välistä sitoutumista ja läheisyyttä sekä keskinäistä ymmärryksen tunnetta. Toisaalta lapsettomuus saattaa aiheuttaa parisuhdekriisin ja nostaa esiin puolisoiden välisiä vanhoja ongelmia. (Tulppala 2002.) Myös vertaiset voivat antaa lapsettomuudesta kärsiville tukea, empatiaa ja mahdollisuuden kuulla ja jakaa henkilökohtaisia kokemuksia. Vertaistuen jakamiseen on kuitenkin havaittu liittyvän positiivisen tuen lisäksi myös negatiivisia ilmiöitä, kuten jaetun tiedon mahdollinen virheellisyys ja toisten osallistujien raskauden tai negatiivisten kokemusten aiheuttamat haitalliset tunteet. (Hinton ym. 2010; Ketokivi 2009; Lundin \& Elmerstig 2015; Malik \& Coulson 2010a; Malik \& Coulson 2010b; ks. myös Räisänen \& Kaunonen 2004.) Vaikka vertaistuki ei sellaisenaan rinnastu samankaltaisuuden kokemuksiin, samankaltaisuuden kokemus voi olla edellytys vertaistuelle. 


\section{TutKimuksen TOTEUTTAMINEN}

\section{Aineisto}

Tutkimuksemme aineiston muodostavat 22 tahattomasti lapsettoman naisen kirjoitelmaa, jotka on kerätty vuonna 2016 Facebookissa, Lapsettomien yhdistys Simpukka ry: $\mathrm{n}^{1}$ kautta. Simpukka ry:n luvalla julkaistiin neljässä tahattomasti lapsettomien vertaistukiryhmässä kirjoituspyyntö, jossa pyydettiin kirjoittamaan tahattoman lapsettomuuden kokemuksista seitsemän teeman kautta: tahattoman lapsettomuuden vaikutuksista 1) naiseuteen, 2) sosiaalisiin suhteisiin, 3) parisuhteeseen ja 4) osallisuuden kokemuksiin sekä 5) yhteiskunnan ja kulttuurin vaikutuksesta tahattoman lapsettomuuden kokemuksiin, 6) kokemusten heijastumisesta työelämään ja 7) selviytymiskeinoista tahattomassa lapsettomuudessa. Tutkimuksen aineiston keruusta vastasi Jenni Katajisto.

Tutkimukseen osallistuneet ovat 22-44-vuotiaita naisia, joiden tahattoman lapsettomuuden kokemus on jatkunut 2-9 vuotta. Pääasiassa kirjoittajat elävät heteroparisuhteessa, mutta mukana on myös yksi kirjoitelma naiselta, jonka puoliso on nainen. Lapsettomuuden taustalla on paikannettavissa sekä selittämätöntä että diagnosoitua lapsettomuutta. Aineistossa ei ole eritelty onko taustalla tai parhaillaan käynnissä lapsettomuushoitoja.

Tutkimusaineistoa kertyi yhteensä 86 tekstisivua. Pisin kirjoitelma on 12 sivua ja lyhin yhden sivun mittainen. Keskimääräinen pituus on noin 4 sivua (Times New Roman, pistekoko 12, riviväli 1). Kirjoitelmat ovat ajallisesti etenevästi kirjoitettuja kertomuksia tahattomaan lapsettomuuteen liittyvistä merkityksellisistä kokemuksista. Pääosassa kirjoitelmia naiset kirjoittivat antamistamme teemoista vapaamuotoisesti. Vaikka antamamme ohjeistuksen muodossa ohjailimme kirjoitelmien tematiikkaa, kuitenkin lopullisen ratkaisun siitä, mitä naiset kirjoittavat, tekivät he itse (ks. esim. Eskola \& Suoranta 2008). Jokainen kirjoitelma oli omanlainen pieni kertomus tahattomasti lapsettoman naisen elämästä.

\section{Tutkimusmenetelmä ja analyysin kulku}

Saadaksemme otteen tahattomasti lapsettomien naisten kirjoituksissaan kuvaamista toiseuden kokemuksista hyödynnämme aineiston analyysivälineenä sisällönanalyysia (Krippendorff 2004; Tuomi \& Sarajärvi 2009). Sen avulla erittelemme kirjoituksista tahattomasti lapsettomien naisten kokemuksia toiseudesta. Kysymme, miten tahattomasti lapsettomat naiset kokevat toiseuden sekä ketkä ja mitkä tekijät synnyttävät heille toiseuden kokemuksia?

Tavoitteenamme on sisällönanalyysin keinoin järjestellä kirjoitelma-aineisto tiiviiseen ja selkeään muotoon kadottamatta sen sisältämää informaatiota. Pyrimme näin luomaan selkeän ja yleisen kuvauksen tutkittavasta ilmiöstä (Grönfors 1982; Krippendorff 2004; Tuomi \& Sarajärvi 2009).

Aineiston varsinainen analyysiprosessi jakautui kolmeen toisiinsa kietoutuneeseen osaan: kirjoitelmiin tutustumiseen, yhteisten ajatusten alustavaan koontiin ja kirjoitelmien sisällönanalyyttiseen lähiluentaan. Aloitimme analyysin lukemalla läpi tutkimuskysymyksemme ohjaamana naisten kirjoituksia 
ja keskustelemalla niiden herättämistä ajatuksista. Tämän jälkeen luennassa kiinnitimme huomion siihen, kuinka tahattomasti lapsettomat naiset kirjoitelmissaan määrittelevät naisia eri luokkiin ja kuvaavat omaa lapsettomuuttaan sekä asemoivat itsensä. Ensinnäkin naiset kuvaavat lapsettomuutta eriyttävänä kokemuksena ja samalla tehden eroja naisiin, joilla joko on lapsia tai jotka ovat saamassa niitä. Toiseksi he kuvaavat lapsettomuutta yhdistävänä ja voimaannuttavana kokemuksena niiden naisten kanssa, joilla on lapsettomuuteen liittyviä toiseuden kokemuksia. Usein näihin kuvauksiin liitetään myös yhteiskunnallinen odotus äitiydestä.

Päästäksemme syvemmälle valitsimme kirjoitelmista alustavaan tarkasteluun kaikki tekstikohdat, joissa tulkitsimme naisten kuvaavan eroja tai erilaisuuden kokemuksiaan ja kohdat, joissa naiset nostavat esiin samankaltaisuuden kokemuksia. Tämän jälkeen luokittelimme nämä kokemukset kolmeen alaluokkaan 1) Lapsettomuus eriyttävänä kokemuksena, 2) Lapsettomuus yhdistävänä ja voimaannuttavana kokemuksena ja 3) Lapsen saanti toiseutta tuottavana kokemuksena.

Toiseuden kokemusta kuvaavien otteiden valinnassa noudatimme seuraavia kriteereitä: a) ne osoittavat tahattomasti lapsettomien naisten toiseuden kokemuksen, joko eriyttävänä tai yhdistävänä kokemuksena, ja b) ne tuovat esiin tahattomasti lapsettomien naisten käsityksiä ja/tai kokemuksia äitiydestä.Tarkastelemme valituista otteista kuvauksia siitä, miten tahattoman lapsettomuuden kokemukset eriyttävät ja tuottavat eri- laisuuden kokemuksia suhteessa toisiin ihmisiin sekä miten ne toisaalta yhdistävät ja tuottavat samanlaisuuden ja samaan ryhmään kuulumisen kokemuksia.

\section{Tutkimuksen eettiset lähtökohdat}

Kirjoitelmat ovat tahattomasti lapsettomille naisille turvallinen tapa osallistua tutkimukseen. He voivat itse valita, jakavatko kertomuksensa vai eivät ja kuinka paljon he elämästään jakavat tutkimuksen käyttöön. Tutkimukseen osallistuminen oli heille vapaaehtoista, ja naisia pyydettiin kirjoittamaan kirjoitelmat nimimerkkien suojassa. Tutkija, jolle kirjoitelmat lähetettiin, anonymisoi ne ennen niiden analysointia.

Kirjoitelmia lukiessamme pääsemme lähelle tahattomasti lapsettomien naisten kokemuksia ja se asettaa meidät tutkijoina erityiseen eettiseen vastuuseen. Tutkimusta tehdessämme olemme pyrkineet kunnioittamaan oman tahattoman lapsettomuuden kertomuksensa tutkimukseen antaneita naisia ja antaneet arvon heidän kokemuksilleen. Juhani Pietarisen (2002) mukaan tutkijan tulisi noudattaa tutkimusta tehdessään eettisiä periaatteita. Olemme pyrkineet noudattamaan näitä periaatteita tekemällä näkyväksi tutkimusprosessimme ja tekemämme tutkimukselliset valinnat. Olemme pyrkineet yksityiskohtaisesti kuvaamaan tutkimuksen aineiston ja sen keruun, tutkimuksen kulun, analyysivälineet ja tulosten tulkinnan (ks. Kuula 2006, 11) ja siten lisänneet myös tutkimuksemme luotettavuutta. 


\section{Tulokset}

Tahattomasti lapsettoman naisen toiseus eriyttävänä kokemuksena

Kirjoitelmissaan tahattomasti lapsettomat naiset kuvasivat toiseuden kokemusta tekemällä eron viallisen, epänormaalin ja ehyen, normaalin naisen välille. Epänormaali nainen poikkeaa kulttuurisesta äitiysodotuksesta. Hän ei kykene saamaan lapsia, kun taas normaali nainen kykenee. Kategorioidessaan naiset normaaleihin ja epänormaaleihin tahattomasti lapsettomat naiset samalla tuottavat kuvaa näiden ryhmien yhtenäisyyksistä ja eroavaisuuksista, kuten alla oleva esimerkki osoittaa:

"Ihminen on kaikella tavalla parempi ihminen, normaalimpi aikuinen, ehyempi nainen, kun hän voi kertoa ihania mieltä lämmittäviä tarinoita omista pienokaisistaan. Minä olen joka ryhmässä hylkiö. Ystävieni kanssa olen hylkiö, jolle ei voi enää sanoa mitään. Kollegoideni kanssa olen epäonnistunut nainen, kun en ole ymmärtänyt nuorena itselleni lapsia hankkia."

Otteessa tahattomasti lapseton nainen kategorisoi itsensä normaalista poikkeavaksi; epäonnistuneeksi ja vialliseksi naiseksi, hylkiöksi. Hän näkee normaalin naisen olevan parempi suhteessa lapsettomaan naiseen. Toiseuden kokemuksen naiselle tuottaa lapsettomuus. Määritellessään itsensä hylkiöksi nainen kategorisoi itsensä samalla tahattomasti lapsettomien naisten joukkoon ja tekee eroa normaaleista naisista: työtovereista ja ystävistä, jotka voivat saada lapsia.

Ote osoittaa, että toiseus ei liity pelkästään lapsettomuuteen, vaan myös lapsen hankinnan ajankohtaan; lapset tulisi tehdä nuorena. Normaali nainen, kuten työtoverit ja ystävät, hankkii lapset nuorena, kun taas epänormaali nainen jättää lapsen teon myöhempään ajankohtaan ja altistaa näin itsensä lapsettomuudelle. Taustalla vaikuttaa kulttuurinen käsitys äitiydestä ja siitä, missä vaiheessa lapsia tulisi "hankkia” (ks. Berg 2008; Nätkin 1991).

Tahattomasti lapsettoman naisen toiseuden kokemuksesta nousee esiin oletus, että lapsen saaneet naiset ovat parempia ihmisiä. Tämä arvottaa samalla lapsettomat naiset huonommiksi ja vähempiarvoisiksi. Lapsettomalle naiselle toiseuden kokemus syntyy suhteessa toisiin, ystäviin ja työtovereihin. He eivät puhu hylkiölle, joka ei voi kertoa perhe-elämästään ja lapsistaan tarinoita ja näin osallistua yhteisen tarinavarannon luomiseen ja kokemusten jakamiseen. Kun työtoverit ja ystävät puhuvat toisilleen lapsistaan, ei heidän puheissaan ole tilaa muille tarinoille.

Toiseus yhdistävänä ja voimaannuttavana kokemuksena

Kirjoitelmissa naiset nostavat esiin myös tahattoman lapsettomuuden sekä sen tuottaman toiseuden yhdistävänä ja voimaannuttavana, positiivisena kokemuksena. Tätä tehdessään he samalla myös tekevät eroa lapsettomiin ja lapsellisiin, niin sanottuihin normaaleihin naisiin. Toisilta samaa kokeneilta saatu tuki voimaannuttaa ja lisää yhteenkuuluvuuden tunnetta; en ole yksin suruni kanssa. Kirjoitelmissa esiin nousee kulttuurinen äitiysodotus ja sen murtaminen, kuten myös alla olevassa esimerkkiotteessa: 
"Yhteiskunnassa oletetaan kaikkien haluavan ja saavan lapsia. Me tahattomasti lapsettomat voimme jotenkin puolustautua. Enemmän minua säälittää ne jotka ovat valinneet lapsettoman elämän. Yhteiskunnassa oletetaan kaikkien haluavan ja saavan punaisen tuvan, 2,5 lasta, mukavan työn ja puolison. Aiemmin ei lapsettomuudesta puhuttu, uskon sen olleen samassa suhteessa kuin nykyisinkin. Nyt siitä vain uskalletaan jo puhua ääneen. Omassa perheessä kaksi tätiäni ovat olleet lapsettomia, toinen tahattomasti ja toinen omasta halustaan. Oma isoäitini on kärsinyt lapsettomuudesta minkä vuoksi lasten ikäerot ovat yli 10 vuotta. Näistä asioista ei ole ennen vain puhuttu, nyt ne tulivat vahingossa puheeksi hautajaisissa 2 vuotta sitten. Lapseton täti sanoi oivaltaneensa "ettei hänen tarvitse täyttää tätä maailmaa”, tuo oivallus oli sitten auttanut häntä elämään lapsettomana."

Ote tuo esiin kulttuurisen oletuksen siitä, että kaikkien naisten oletetaan saavan ja haluavan lapsia sekä kuinka vaikeaa kyseisen odotuksen täyttäminen on. Otteessa nainen kategorisoi itsensä samankaltaisten tahattomasti lapsettomien joukkoon "Me". Samalla hän eriyttää itsensä normaaleista lapsia haluavista ja saavista äideistä "He" sekä lapsettoman elämän valinneista vapaaehtoisesti lapsettomista naisista "Ne". Kategorisoidessaan lapsettomat naiset eri ryhmiin kirjoittaja tekee eroa myös lapsettomien naisten välille. Samalla hän tekee näkyväksi, että lapsettomat eivät ole yhtenäinen joukko. Nainen kokee yhteenkuuluvuutta tahattomasti lapsettomien kanssa ja kategorisoi itsensä kuuluvaksi isoäitinsä ja lapsettoman tätinsä kanssa tähän ryhmään. Kuuluminen saman kokeneiden naisten ryhmään voi olla tahattomasti lapsettomalle naiselle voimaannuttava kokemus.
Yhteiskunnassamme kulttuurinen äitiysodotus on vahva ja sen muuttaminen on vaikeaa (ks. Gillespie 2000; Rich ym. 2011; Turnbull ym. 2017). Ennen lapsettomuudesta ei juuri puhuttu, vaan sitä saatettiin pitää perhesalaisuutena ja häpeänä. Nykyisin lapsettomuus ei ole enää vaiettu salaisuus, vaikkakin edelleenkin naiset pohtivat hyvin tarkkaan, kenelle lapsettomuudestaan kertovat. Ote osoittaa, että tänä päivänä tahattomasti lapseton nainen voi nousta esiin ja puolustautua lapsettomuuden tuottamaa häpeää vastaan ja siten kyseenalaistaa lapsettomuuteen liittyvät määritykset ja oletukset. Otteesta nousee myös esiin elämän merkityksellisyyden oivallus: kaikkien naisten ei tarvitse tehdä tai saada lapsia elääkseen merkityksellistä elämää. Tämä on vastapuhetta yhteiskunnassa vallitsevaa ajattelutapaa kohtaan.

Vertaisilta saadun tuen lisäksi positiivista toiseutta on nähtävillä kuvauksessa tahattoman lapsettomuuden vaikutuksesta parisuhteeseen:

\footnotetext{
"Anoppi selitti kerran luettuaan jostain lehdestä, että kyllä hän ymmärtää, että teillä on tosi vaikeaa, kun lapsettomuushan on pahin asia mitä parisuhteelle voi tapahtua. Olin varsin tyrmistynyt, koska silla ihmisellä ei yleensä ollut mitään järkevää sanottavaa asiasta ja nyt hän oli keksinyt omasta päästään (tai lukemastaan naistenlehdestä), että meillä olisi ollut joku erityinen parisuhdekriisi siinä päallimmäisenä ongelmana (siihen suruun hän ei koskaan sanonut mitään). Tiedän tietenkin, että osalla parisuhde kaatuukin näihin. Meillä se oikeastaan aiheutti päinvastaista. Lapsia voi saada kenen kanssa tahansa (melkein). Lapsettomuutta vuodesta toiseen voi kestää vain erityinen ihminen rinnallaan."
} 
Otteessa nainen kuvaa kuinka anoppi tuo esiin oletuksen lapsettomuuden aiheuttamista ongelmista. Tahattomasti lapsettomaan pariskuntaan voi lähiomaisten ja ystävien taholta kohdistua oletus parisuhteen kriisiytymisestä. Lapsettomuuden vaikutukset parisuhteeseen voivat juontua toisaalta niistä lähtökohdista, miksi parisuhde on alun alkaen solmittu ja äitiysodotuksesta (ks. Berg 2008; Lehto 2017; Nätkin 1991).

Otteessa nainen vastapuheella kyseenalaistaa tulkinnan lapsettomuuden aiheuttamasta pahasta. Tahattoman lapsettomuuden kokemus voi asettua myös parisuhdetta vahvistavaksi ja positiivista toiseutta tuottavaksi tekijäksi, jolloin lapsettomuuden kokemus asettuu yhteiseksi suruksi, jota kannetaan yhdessä ja siitä selvitään yhdessä. Otteessa nainen kategorisoi puolisonsa erityiseksi ja nostaa esiin lapsettomuuden parisuhdetta vahvistavana ja pariskuntaa yhdistävänä tekijänä. Yhteinen kokemus hitsaa pariskunnan entistä tiiviimmin yhteen ja syventää puolisoiden välistä ymmärrystä. Samalla hän tuottaa eroavien ja yhdessä pysyvien tahattomasti lapsettomien pariskuntien kategoriat.

Lapsen saanti toiseutta tuottavana kokemuksena

Kirjoitelmissa lapsen saaminen näyttäytyy sekä positiivista että negatiivista toiseutta tuottavana kokemuksena. Toiseutta syntyy sekä toisen tahattomasti lapsettoman naisen saadessa lapsen että silloin, kun tahattomasti lapseton nainen itse saa lapsen.

"Raskasta on myös, että moni kohtalotoverikin on jo siirtynyt "sinne paremmalle puolelle", mikä on toisaalta ihana ja luo paljon toivoa tulevaan mutta samalla tärkeä vertaistukirinki kapenee, eikä ole enää niin montaa kenelle tuskailla negatiivisia testejä ja alkavia kunkautisia."

Otteessa nainen kategorisoi itsensä tahattomasti lapsettomien naisten ryhmään ja lapsen saaneet aiemmin tahattomasta lapsettomuudesta kärsineet naiset lapsellisten naisten ryhmään. Lisäksi nainen tekee eroa tahattomasti lapsettomien naisten ryhmän ja lapsen saaneiden ryhmän välille määritellessään ja arvottaessaan jälkimmäisen ryhmän paremmaksi. Siirtymät "paremmalle puolelle" luovat toivoa siitä, että lapsen saanti on mahdollista ja että oma siirtymä voi tapahtua tulevaisuudessa. Toisaalta nainen on onnellinen siitä, että joku heidän ryhmästään saa lapsen ja tämän toive toteutuu, mutta samalla tahattomasti lapsettomien naisten ryhmä pienenee ja kapenee, jolloin vertaisia, joiden kanssa jakaa kokemuksia lapsettomuudesta, on yhä vähemmän.

Silloin kun siirtymä "paremmalle puolelle" toteutuu tahattomasti lapsettoman naisen omalla kohdalla, voi odotuksena olla eriyttävien, negatiivisten toiseuden kokemusten päättyminen:

"Sukulaiset, jotka eivät viitsineet pitää $\gamma h$ teyttä munten, lähettivät onnitteluja ja ottivat yhteyttä. Samoin ne vanhat ystävät, joista ei ollut kuulunut mitään aikoihin. Meitä kutsuttiin perheviikonlopputapaamisiin, joihin aiemmin emme olleet kelvanneet. Silloin koin vahvasti sen, kuinka suuri kuilu sosiaalisesti on olla lapseton/lapsia saanut. [--] Ja voisi kuvitella, että nyt happy end ja siihen loppui lapsettomuus, mutta ei se oikeastaan loppunut. [--] Koin olevani äarimmäisen huono ja epäkelpo äitinä. Minun epäkelpouteni ei siis liittynyt naiseuteen tai 
yhteiskunnan tai suvun jäsenyyteen tai vaimouteen vaan täsmälleen juurikin äitiyteen ja oma lapsettomuuteni aiheuttama epäkelpouden tunne roihusi äitiyteni ensimmäiset puoli vuotta hyvinkin näännyttävästi."

Ote osoittaa kuilun lapsettoman pariskunnan ja lapsiperheiden välillä. Lapsettomuuden myötä yhteys sukulaisiin ja ystäviin etääntyy ja kuilu kasvaa. Lapsen saannin myötä yhteydet voivat aktivoitua uudelleen ja kuilu tämän myötä kaventua. Pääsy sosiaalisiin suhteisiin, joihin ei lapsettomuuden vuoksi ole aiemmin ollut mahdollisuutta, voi siten alleviivata lapsettomien kokemaa eriyttävää toiseutta, vaikka itse lapsettomuus olisikin päättynyt.

Tahattoman lapsettomuuden kokemus ei välttämättä lopu siihen, että saa lapsen. Lapsen saadessaan naiset kategorisoituvat uudelleen lasten saaneiden ryhmään, mutta eivät kuitenkaan normaalinaisten ryhmään vaan niiden tahattomasti lapsettomien naisten ryhmään, jotka ovat saaneet lapsen. Lapsettomuus voi myös jäädä kiinni naisen identiteettiin, jolloin syntyy jälleen toiseuden kokemus suhteessa muihin äiteihin. Omaan äitiyteen voi kohdistua valtavia suorituspaineita, mikä pahimmillaan eriyttää muista äideistä, joilta voisi saada tukea äitiyteen. Irtautuminen tahattomasti lapsettoman naisen kategoriasta ei välttämättä onnistukaan heti varsinaisen lapsettomuuden päätyttyä.

\section{Pohdinta}

Tässä tutkimuksessa nostimme tarkastelun kohteeksi tahattomasti lapsettomien naisten kokemukset toiseu- desta. Kysyimme, miten tahattomasti lapsettomat naiset kokevat toiseuden sekä ketkä ja mitkä tekijät synnyttävät heille toiseuden kokemuksia? Tahattomasti lapsettomien naisten kirjoitelmista $(N=22)$ paikansimme kolme erilaista toiseuden kokemuksen tapaa, jotka sisältävät moninaisia toiseuden tuottamisen dynamiikkoja. Ne ovat: 1) Lapsettomuus eriyttävänä kokemuksena, 2) Lapsettomuus yhdistävänä ja voimaannuttavana kokemuksena ja 3) Lapsen saanti toiseutta tuottavana kokemuksena.

Usein tahattomasti lapsettomia naisia pidetään uhreina (Watkins \& Baldo 2004, 397), joita kokemus lapsettomuudesta eriyttää ja marginalisoi (Benasutti 2003; Rotkirch ym. 2017; Turnbull ym. 2017). Lisa Hinton kumppaneineen (2010) on eritellyt tahattoman lapsettomuuden aiheuttamia eristäytymisen ja eriytymisen syitä. Näitä ovat muun muassa perheen ja ystävien ymmärtämättömyys surun syvyydestä, kateus muiden, myös täysin tuntemattomien ihmisten, raskaudesta tai lapsista sekä kokemus kontrollin menettämisestä oman elämänsä suhteen (Hinton ym. 2010; ks. myös Watkins \& Baldo 2004). Kirjoitelmien naisten kokemus tahattomasta lapsettomuudesta oli moninaisempi. Vaikka toisten tekemät määritelmät naisen lapsettomuudesta ja sen syistä sekä parisuhteesta ja sen ongelmista loukkasivat naisia ja tuottivat eriyttäviä kokemuksia, naiset eivät kuitenkaan nähneet tahatonta lapsettomuutta vain negatiivisessa valossa. He kuvasivat tahatonta lapsettomuutta myös yhdistävänä kokemuksena, joka auttaa selviytymään. Siten naisten kokemus lapsettomuudesta ja sen tuottamasta toiseudesta paikantui osittain ristiriitaiseksi. 
Koettu negatiivinen toiseus ohjasi naisia hakemaan tukea vertaisilta (Hinton ym. 2010). Vertaistuki ja samankaltaisuus yhdistivät ja tuottivat positiivista toiseutta tahattomasti lapsettomille naisille. Räisäsen ja Kaunosen (2004) mukaan negatiiviset kokemukset kuluttavat lapsettomien voimavaroja, kun taas positiiviset kokemukset vahvistavat niitä (ks. myös Tulppala 2012).Vastapuheen avulla naiset pyrkivät haastamaan ja siten muuttamaan tahattomaan lapsettomuuteen liittyviä negatiivisia mielikuvia ja määrityksiä sekä tuomaan esiin lapsettomuuteen liittyviä positiivisia kokemuksia. Näemme positiivisten toiseuden kokemusten vahvistavan mahdollisuuksia tahattoman lapsettomuuden negatiivisista kokemuksista selviytymiseen.

Tahattomasti lapsettomille naisille lapsettomuus ja äitiys näyttäytyivät moninaisina. Naisten kirjoitelmista oli paikannettavissa me, he ja ne ryhmäkategoriat, joita naiset arvottivat eri tavoin. Näiden erilaisten kategorioiden taustalla on ajatus äitiydestä ja siitä, millainen nainen mihinkin ryhmään kuuluu (ks. esim. Parry 2005; Ulrich \& Weatherall 2000). Naiset luokittelivat tahattomasti lapsettomat naiset oman ryhmänsä jäseniksi: me. Ryhmän jäsenille tahaton, ei omaan valintaan pohjautuva, lapsettomuuden kokemus synnytti keskinäisen yhtenäisyyden ja samanlaisuuden tunteen. Toiseksi naiset tekivät eron tahattomasti lapsettomien eli poikkeavien ja normaalisti lapsia saavien naisten välille: he. Näitä ryhmiä erotti kokemus lapsettomuudesta ja äitiydestä. Naiset arvostivat, jopa kadehtivat, lapsen saaneiden naisten kokemusta äitiydestä. Kolmanneksi naiset tekivät kirjoitelmissa eron tahattomasti ja va- paaehtoisesti lapsettomien naisten välille: ne. Ryhmiä yhdisti ja erotti kokemus lapsettomuudesta. Vapaaehtoisesti lapseton nainen oli tehnyt valinnan siitä, että ei halua lapsia. Kirjoitelmissa tahattomasti lapsettomat naiset arvostivat vähemmän, säälivät ja ihmettelevät tämän valinnan tehneitä naisia. He eivät olisi itse päätyneet kyseiseen valintaan (ks. Gillespie 2000). Neljänneksi kirjoitelmissa nousee ero tavallisten äitien ja tahattoman lapsettomuuden kokeneiden äitien välille. Ryhmiä yhdisti lapsi ja äitiys sekä erotti kokemus tahattomasta lapsettomuudesta.

Lapsettomien naisten luokittelu ja arvottaminen eri tavoin nostaa esiin kulttuurisen äitiysodotuksen vahvuuden ja voiman (ks. esim. Isola 2012; Nätkin 1991). Anna Rotkirch ja kumppanit (2017, 49-50) näkevät, että lapsettomuus on edelleen leimaavaa, vaikka tahaton lapsettomuus ymmärretäänkin yhteiskunnassamme paremmin kuin vapaaehtoinen lapsettomuus. Kirjoitelmissa naiset uusintavat kulttuurista äitiysodotusta pitämällä äitiyttä normaalin naisen tehtävänä sekä tahatonta ja vapaaehtoista lapsettomuutta poikkeavana. Tämä kulttuurisen äitiysodotuksen vaikutus heijastuu tahattoman lapsettomuuden kokeneiden naisten elämään vielä silloinkin, kun heistä tulee äitejä (ks. myös Lehto 2017).

Siirtymä tahattomasti lapsettomasta lapsen saaneiden naisten ryhmään ei välttämättä poista naisille syntynyttä toiseuden kokemusta. Ennemminkin kokemus tuotti heille moninaisia tunteita. Tahattomasti lapsettomat naiset toivoivat lasta ja siirtymää normaalien lapsen saaneiden naisten ryhmään, mutta samalla he kokivat menettävänsä 
tahattomasti lapsettomien naisten ryhmän ja vertaistuen. Siten tahattomasti lapsettomalle naiselle raskaaksi tulemiseen ja/tai lapsen saamiseen voi liittyä myös negatiivisia tunteita. Tahattomasti lapsettomat naiset eivät aina tunne kuuluvansa tavallisten lapsen saaneiden naisten joukkoon, vaan tahattoman lapsettomuuden kokemus voi vaikuttaa heidän äitiyteensä ja herättää kysymyksen siitä, mihin kuulun ja kenen kanssa voin jakaa tahattoman lapsettomuuden sävyttämiä raskauden ja äitiyden kokemuksia. Monika Mynarskan ja kumppaneiden (2015, 44-45) mukaan tahaton lapsettomuus on prosessi, joka voi jäädä elämässä taka-alalle lapsen saannin myötä. Tutkimukseemme osallistuneet naiset kokivat, että tahattoman lapsettomuuden kokemus kulkee heidän mukaan sävyttäen heidän äitiyttään ja elämäänsä. Niille, joille siirtymät tahattomasti lapsettomien ryhmästä pois antoi odotuttaa, kokemus vertaisen raskaudesta oli usein ristiriitainen. Se antoi toivoa mutta samalla se nosti negatiiviset epäonnistumisen ja häpeän kokemukset esiin.

Tahattomalla lapsettomuudella on pitkäaikaisia vaikutuksia naisten elämään (Parry 2005). Lapsettomuuden kokeminen ja sen tuottama toiseuden kokemus saattavat ohjata naisia hakemaan tukea ja apua lapsettomuuden kokeneilta toisilta tai omalta puolisolta lieventääkseen lapsettomuuden aiheuttamia negatiivisia kokemuksia. Aiemmassa tutkimuksessa selviytymistä tukeviksi keinoiksi on tunnistettu yhteiskunnassa tapahtunut perhekäsityksen monimuotoistuminen, sosiaaliselta ympäristöltä ja läheisiltä saatu tuki, tulevaisuuden uudelleen määritteleminen sekä elämän ja arjen merkityksel- lisyyden löytäminen lapsettomuudesta huolimatta (Gameiro \& Finnigan 2017, Kettula-Pihlaja ym. 2015; Su \& Chen 2006; Watkins \& Baldo 2004). Tässä tutkimuksessa merkitykselliseksi sosiaaliseksi tueksi vertaistuen ohelle nousivat puolisot. Puolison kanssa jaettiin kokemukset lapsettomuuden tuottamasta surusta ja äitiysodotuksen tuomista toiseuden kokemuksista. Keskeistä on, että tahattomasti lapsettomille suunnatuissa palveluissa ja vertaistuen piirissä puhutaan yhdessä kulttuurisen äitiysodotuksen vaikutuksista naisten kokemuksiin sekä avataan lapsettomuuteen liittyviä positiivisia ja negatiivisia toiseuden kokemuksista. Lapsettomuuden hyväksyminen ilmenee lapsettomuuteen sopeutumisena, jota edesauttaa positiivinen elämänasenne ja avoimuus (Räisänen \& Kaunonen 2004). Näiden vahvistamisessa niin ammattilaisilla, vertaisilla kuin puolisoilla ja muilla läheisillä on oma tärkeä roolinsa.

Tutkimusta lukiessa on hyvä ottaa huomioon, että kaikki lapsettomat naiset eivät välttämättä koe samalla lailla positiivisia, ristiriitaisia ja/tai negatiivisia toiseuden kokemuksia. Tähän tutkimukseen osallistuneet naiset ovat pieni ryhmä tahattomasti lapsettomien naisten joukosta. Lisäksi on hyvä ottaa huomioon myös se, että osallistujat on rekrytoitu Lapsettomien yhdistys Simpukka ry:n Facebook-ryhmän kautta. Tämä on osaltaan rajoittanut tutkimukseen osallistuneiden joukkoa ja saattanut vaikuttaa siihen, miten osallistujat kirjoittavat lapsettomuudestaan. Siten ei voida olettaa, että kaikki tahattomasti lapsettomat kokevat lapsettomuuden tietyllä tavoin, vaan heidän kokemansa toiseuden kokemus on yksilöllinen (ks. Greil ym. 2010, 145). Tässä tutki- 
muksessa on yritetty saada kiinni näitä yksilöllisiä kokemuksia yhdistävistä piirteistä ja tuoda esiin myös kokemusten moninaisuus. Jatkossa olisi tarpeen suunnata tutkimuksellinen katse myös tahattomasti lapsettomien naisten puolisoiden kokemuksiin toiseudesta sekä tukikeinoihin, joilla vahvistaa positiivisen toiseuden kokemuksia.

1) Haluamme kiittää Simpukka ry:tä ja erityisesti tutkimukseen osallistuneita naisia siitä, että jaoitte kokemuksenne kanssamme sekä Jenni Katajistoa tutkimusaineiston keräämisestä ja jakamisesta kanssamme.

\section{KirJallisuUs}

Benasutti, Rita Diana (2003) Infertility: experiences and meanings. Journal of Couple \& Relationship Therapy: Innovations in Clinical and Educational Interventions 2 (4), 51-71. https://doi. org/10.1300/J398v02n04_04

Berg, Kristiina (2008) Äitiys kulttuurisina odotuksina. Väestöntutkimuslaitoksen julkaisusarja D 48/2008. Helsinki:Väestöliitto.

Carmichael, Gordon A. \& Whittaker, Andrea (2007) Choice and circumstance: Qualitative insights into contemporary childlessness in Australia. European Journal of Population 23 (2), 111-143. https://doi.org/10.1007/s10680-0069112-4

Eskola, Juha \& Suoranta, Jari (2008) Johdatus laadulliseen tutkimukseen. Tampere: Vastapaino.

Fiori, Francesca \& Rinesi, Francesca \& Graham, Elspeth (2017) Choosing to remain childless? A comparative study of fertility intentions among women and men in Italy and Britain. European Journal of Population 33 (3), 319-350. https://doi. org/10.1007/s10680-016-9404-2

Gameiro, Sofia \& Finnigan, Amy (2017) Long-term adjustment to unmet parenthood goals following ART: a systematic review and meta-analysis. Human
Reproduction Update 23 (3), 322-337. https://doi.org/10.1093/humupd/ dmx001

Gillespie, Rosemary (2000) When no means no: Disbelief, disregard and deviance as discourses of voluntary childlessness. Women's Studies International Forum 23 (2), 223-234. https://doi.org/10.1016/ S0277-5395(00)00076-5

Graham, Melissa (2015) Is being childless detrimental to a woman's health and wellbeing across her life course? Women's Health Issues 25 (2), 176-184. https:// doi.org/10.1016/j.whi.2014.12.002

Greil, Arthur \& Slauson-Blevins, Kathleen \& McGuillan, Julia (2010) The experience of infertility: A review of recent literature. Sociology of Health \& Illness 32 (1), 140-162. https://doi.org/10.1111/ j.1467-9566.2009.01213.x

Grönfors, Martti (1982) Kvalitatiiviset kenttätyömenetelmät. Helsinki:WSOY.

Hall, Stuart (1999) Identiteetti. Mikko Lehtonen \& Juha Hekman (suom. \& toim.) Tampere:Vastapaino.

Hall, Christopher \& Slembrouck, Stef \& Sarangi, Srikant (2006) Language practices in social work. Categorisation and accountability in child welfare. London: Routledge.

Herrmann, Darja \& Scherg, Horst \& Verres, Rolf \& von Hagens, Cornelia \& Strowitzki, Thomas \& Wischmann, Tewes (2011) Resilience in infertile couples acts as a protective factor against infertility-specific distress and impaired quality of life. Journal of Assisted Reproduction and Genetics 28 (11), 1111-1117. https:// doi.org/10.1007/s10815-011-9637-2

Hinkkanen, Reea (2009) 'Someone to welcome you home' - Infertility, medicines and the Sukuma-Nyamwezi. Research Series in Anthropology. Helsinki: Helsinki University.

Hinton, Lisa \& Kurinczuk, Jennifer \& Ziebland, Sue (2010) Infertility; isolation and the Internet: A qualitative interview study. Patient Education and Counseling 81 (3), 436-441. https://doi. org/10.1016/j.pec.2010.09.023

Huttunen, Laura (2004) Kasvoton ulkomaalainen ja kokonainen ihminen: marginalisoiva kategorisointi ja maahanmuuttajien vastastrategiat. Teoksessa 
Arja Jokinen \& Laura Huttunen \& Anna Kulmala (toim.) Puhua vastaan ja vaieta: neuvottelu kulttuurisista marginaaleista. Helsinki: Gaudeamus, 134-154.

Häggman, Kai (1994) Perheen vuosisata. Perheen ihanne ja sivistyneistön elämäntapa 1800-luvun Suomessa. Historiallisia tutkimuksia 179. Helsinki: Suomen Historiallinen Seura.

Isola, Anna-Maria (2012) Hyviä työntekijöitä ja veronmaksajia. Syntyvyysretoriikka 2000-luvun alun Suomessa. Janus 20 (3), 334-352.

Jokinen, Arja \& Huttunen, Laura \& Kulmala, Anna (2004) Johdanto: Neuvottelu marginaalien kulttuurisesta paikasta. Teoksessa Arja Jokinen \& Laura Huttunen \& Anna Kulmala (toim.) Puhua vastaan ja vaieta. Neuvottelu kulttuurisista marginaaleista. Helsinki: Gaudeamus, 9 - 19. https://doi.org/10.1093/ gao/9781884446054.article.T039620

Juhila, Kirsi (2004) Leimattu identiteetti ja vastapuhe. Teoksessa Arja Jokinen \& Laura Huttunen \& Anna Kulmala (toim.) Puhua vastaan ja vaieta. Neuvottelut kulttuurisista marginaaleista. Helsinki: Gaudeamus, 20-32.

Juhila, Kirsi (2012) Poikkeavan kategoria jäsenyyden tuottaminen ja vastustaminen. Teoksessa Arja Jokinen \& Kirsi Juhila \& Eero Suoninen (toim.) Kategoriat, kulttuuri \& moraali. Tampere:Vastapaino, 175-226.

Julkunen, Raija (2010) Sukupuolen järjestykset ja tasa-arvon paradoksit. Tampere: Vastapaino.

Katajisto, Jenni (2016) Vajanaisesta KokoNaiseksi: Narratiivinen tutkimus naisten tahattoman lapsettomuuden kokemuksista ja kosketuspinnoista. Pro gradu -tutkielma. Tampere: Tampereen yliopisto, Yhteiskunta- ja kulttuuritieteiden yksikkö.

Ketokivi, Kaisa (2009) Sharing the same fate. The social bond between the self and fellow sufferers in the context of peer support. European Societies 11 (3), 391-410. https://doi. org/10.1080/14616690902764815

Kettula-Pihlaja, Tanja \& Aho, Anna Liisa \& Kaunonen, Marja (2015) Haikaran ohilento - Lapsettomuudesta selviytyminen naisten kuvaamana. Hoitotiede 27 (4),
298-310.

Kuivasaari-Pirinen, Paula (2013) The pathway from infertility to parenthood through assisted repro-ductive technology (ART). Dissertations in Health Sciences 159. Kuopio: Itä-Suomen yliopiston julkaisuja.

Kulmala, Anna (2006) Kerrottuja kokemuksia leimatusta identiteetistä ja toiseudesta. Acta Electronica Universitatis Tamperensis 523. Tampere: Tampere University Press.

Kuula, Arja (2006) Tutkimusetiikka: aineistojen hankinta, käyttö ja säilytys. Tampere:Vastapaino.

Krippendorff, Klaus (2004) Content analysis. An introduction to its methodology. Toinen painos. Thousand Oaks: Sage Publications.

Lehto, Siru (2017) Äidiksi tulon kulttuurisen mallitarinan rikkoutuminen tahattoman lapsettomuuden läpikäyneiden naisten kertomuksissa. Psykologia 52 (5), 391-406.

Letherby, Gayle (1999) Other than mother and mothers as others: The experience of motherhood and non-motherhood in relation to 'infertility' and involuntary childlessness. Women's Studies International Forum 22 (3), 359-372. https://doi.org/10.1016/S02775395(99)00028-X

Letherby, Gayle (2002) Challenging dominant discourses: identity and change and the experience of 'infertility' and 'involuntary childlessness'. Journal of Gender Studies 11 (3), 277-288. https://doi .g/10.1080/0958923022000021241

Luk, Bronya \& Loke, Alice (2015) The impact of infertility on the psychological well-being, marital relationships, sexual relationships, and quality of life of couples: A systematic review. Journal of Sex \& Marital Therapy 41 (6), 610625. https://doi.org/10.1080/009262 3X.2014.958789

Lundin, Ulrika \& Elmerstig, Eva (2015) "Desire? Who needs desire? Let's just do it!"- a qualitative study concerning sexuality and infertility at an internet support group. Sexual and Relationship Therapy 30 (4), 433-447. https://doi.org/10.108 0/14681994.2015.1031100

Löytty, Olli (2005a) Kuinka tutkia kohtaa- 
misia ja valtaa. Teoksessa Anna Rastas \& Laura Huttunen \& Olli Löytty (toim.) Suomalainen vieraskirja: Kuinka käsitellä moni-kulttuurisuutta. Tampere: Vastapaino, 161-189.

Löytty, Olli (2005b) Johdanto: Toiseutta ja tilakurittomuutta. Teoksessa Olli Löytty (toim.) Rajanylityksiä. Tutkimusreittejä toiseuden tuolle puolen. Helsinki: Gaudeamus, 7-24.

Malik, Sumaira H. \& Coulson, Neil S. (2010a) Coping with infertility online: an examination of self-help mechanisms in an online infertility support group. Patient Education and Counselling 81 (2), 315-318. https://doi.org/10.1016/j. pec.2010.01.007

Malik, Sumaira H. \& Coulson, Neil S. (2010b) 'They all supported me but I felt like I suddenly didn't belong anymore': an exploration of perceived disadvantages to online support seeking. Journal of Psychosomatic Obstetrics \& Gynecology 31 (3), 140-149. https://doi.org/10.310 9/0167482X.2010.504870

Malin, Maili (2006) Biovalta, toiseus ja naisten toimijuus hedelmöityshoidoissa. Tutkimuksia 156. Helsinki: Stakes.

McCarthy, Patrice (2008) Women's lived experience of infertility after unsuccessful medical intervention. Journal of Midwifery \& Women's Health 53 (4), 319-324. https://doi.org/10.1016/j. jmwh.2007.11.004

Miettinen, Anneli (2010) Voluntary or involuntary childlessness? Socio-demographic factors and childlessness intentions among childless Finnish men and women aged 25-44. Finnish Yearbook of Population Research 45, 5-24. https:// doi.org/10.23979/fypr.45051

Miettinen, Anneli (2011) Äidiksi ja isäksi hedelmöityshoidolla. Väestöntutkimuslaitos Katsauksia E 40. Helsinki: Väestöliitto.

Miettinen,Anneli \& Rotkirch,Anna (2008) Milloin on lapsen aika? Lastenhankinnan toiveet ja esteet. Perhebarometri 2008. Väestöntutkimuslaitos. Katsauksia E 34. Helsinki:Väestöliitto.

Miettinen, Anneli \& Rotkirch, Anna \& Szalma, Ivett \& Donno, Annalisa \& Tanturri, Maria-Letizia (2014) Increasing childlessness in Europe: time trends and country differences. Väestöliiton Väestöntutkimuslaitoksen työpaperi 2014 (5) Helsinki:Väestöliitto.

Miettinen, Anneli (2015) Miksi syntyvyys laskee? Suomalaisten lastensaantiin liittyviä toiveita ja odotuksia. Väestöntutkimuslaitos, Katsauksia E 49. Helsinki: Väestöliitto.

Morison, Tracy \& Macleod, Catriona \& Lynch, Ingrid \& Mijas, Magda \& Shivakumar, Seemanthini Tumkur (2016) Stigma resistance in online childfree communities: The limitations of choice rhetoric. Psychology of Women Quarterly 40 (2), 184-198. https://doi. org/10.1177/0361684315603657

Mynarska, Monika \& Matysiak, Anna \& Rybinska, Anna \& Tocchioni, Valentina \& Vignoli, Danieli (2015) Diverse paths into childlessness over the life course. Advances in Life Course Research 25, 35-48. https://doi.org/10.1016/j. alcr.2015.05.003

Mäkinen, Arja (2008) Vanhojapiikoja ja vapaita naisia. Helsinki: Kirjapaja.

Nätkin, Ritva (1991) Siveettömät, itsekkäät, emansipeeratut. Teoksessa Sinikka Nopola (toim.) Äiti tuu ikkunaan. Äitiys - elämä vai kohtalo? Porvoo: WSOY, $11-26$.

Parry, Diana C. (2004) Women's lived experiences with infertility. Canadian woman studies 24 (1), 81-86.

Parry, Diana C. (2005) Work, leisure, and support groups: An examination of the ways women with infertility respond to pronatalist ideology. Sex Roles 53 (5-6), 337-346. https://doi.org/10.1007/ s11199-005-6757-0

Patosalmi, Mervi (2011) The politics and policies of reproductive agency. Helsinki: Helsingin yliopisto.

Pietarinen, Juhani (2002) Eettiset perusvaatimukset tutkimustyössä. Teoksessa Sakari Karjalainen \& Veikko Launis \& Risto Pelkonen \& Juhani Pietarinen (toim.) Tutkijan eettiset valinnat. Helsinki: Gaudeamus, 58-69.

Repokari, Leena (2008) Transition to parenthood after assisted reproductive treatment: Follow-up study of singleton pregnancies. Helsinki: Helsingin yliopisto.

Rich, Stephanie \& Taket, Ann \& Graham, 
Melissa \& Shelley, Julia (2011) 'Unnatural', 'unwomanly', 'uncreditable' and 'undervalued': The significance of being a childless woman in Australian society. Gender Issues 28 (4), 226-247. https:// doi.org/10.1007/s12147-011-9108-1

Rotkirch, Anna \& Tammisalo, Kristiina \& Miettinen, Anneli \& Berg, Venla (2017) Miksi vanhemmuutta lykätään? Nuorten aikuisten näkemyksiä lastensaannista. Perhebarometri 2017. Väestöliitto: Helsinki

Räisänen, Ritva \& Kaunonen, Marja (2004) Lapsettomuus kokemuksena Internetin keskustelupalstalla. "Saisi haikara jo pian palvella minuakin, voisikohan mihinkään valittaa kohtuuttomaksi venähtäneestä jonotusajasta!?”. Hoitotiede 16 (2), 71-80.

Su, Tsann-Juu \& Chen, Yueh-Chih (2006) Transforming hope: The lived experience of infertile women who terminated treatment after in vitro fertilization failure. Journal of Nursing Research 14 (1), 46-54. https://doi.org/10.1097/01. JNR.0000387561.03823.8e

Tanturri, Maria Letizia \& Mencarini, Letizia (2008) Childless or childfree? Paths to voluntary childlessness in Italy. Population and Development Review 34 (1), 51-77. https://doi.org/10.1111/j.17284457.2008.00205.x

Tulppala Maija (2002) Lapsettomuuden tuska. Duodecim 118, 531-536.
Tulppala Maija (2012) Lapsettomuus ja parisuhde. Suomen Lääkärilehti 26-31 (67), 2081-2086.

Tuomi, Jouni \& Sarajärvi, Anneli (2009) Laadullinen tutkimus ja sisällönanalyysi. Helsinki:Tammi.

Turnbull, Beth \& Graham, Melissa \& Taket, Ann (2017) Pronatalism and social exclusion in Australian society: Experiences of Women in their Reproductive Years with No Children. Gender Issues 34 (4), 333 354. https://doi.org/10.1007/s12147016-9176-3

Ulrich, Miriam \& Weatherall, Ann (2000) Motherhood and infertility: Viewing motherhood through the lens of infertility. Feminism \& Psychology 10 (3), 323-336. https://doi. org/10.1177/0959353500010003003

Watkins, Kathryn \& Baldo, Tracy (2004) The infertility experience: Biopsychosocial effects and suggestions for Counselors. Journal of counseling \& Development 82 (4), 394-402. https:// doi.org/10.1002/j.1556-6678.2004. tb00326.x

Yli-Kuha, Anna-Niina (2012) Prevalence and socio-demographic determinants of infertility, success of infertility treatments and health of treated women. Acta Universitatis Tamperensis 1691. Tampere: Tampere University Press. 